\title{
Stakeholder's Perspective on Risks Allocation in Design and Build Projects in Malaysia
}

\author{
Sabihah Saaidin ${ }^{1, *}$, Intan Rohani Endut ${ }^{1}$, Siti Akmar Abu Samah ${ }^{2}$, and Ahmad Ruslan \\ Mohd Ridzuan ${ }^{1}$ \\ ${ }^{1}$ Faculty of Civil Engineering, Universiti Teknologi MARA, 40450 Shah Alam, Selangor, Malaysia \\ ${ }^{2}$ Academy of Language Studies, Universiti Teknologi MARA, 40450 Shah Alam, Selangor, Malaysia
}

\begin{abstract}
Design and Build (DB) projects are prone with high risks. The appropriate risk allocation among contracting parties in Design and Build (DB) projects is an important and essential decision leading to the project performance. The establishment of risk allocation at early stage of the projects will contribute great impact to the project objective. It is required judgement and experiential knowledge of the construction experts to determine the appropriateness of risk allocation to the parties involved in DB projects. Therefore, this study has been carried out to investigate and determine the most responsible parties that should handle the risk in DB projects. A total of 170 responses from stakeholder's (Client, Consultant and Contractor) were received and analysed by using descriptive statistics and Kruskal-Wallis test. Sixty-four risk allocation criteria were used and the results of these analyses shows that 41 risks allocated to the contractor, 9 risks allocated to the client, 6 risks allocated to the consultant, and 8 risks are undecided. There were 17 risks allocations were found with significant differences in between stakeholders on their perceptions. This paper is to help stakeholders define clearly their responsibilities on risks in DB projects and make a better decision in handling it.
\end{abstract}

\section{Introduction}

Risks are inherent to all construction projects regardless of the size. Among a variety of risks, a contractor usually takes on many speculative risks especially in design and build (DB) projects. The Design and Build (DB) contract is an innovative procurement method whereby a single contractor is responsible for the design and construction to deliver a construction project for the client. Risk in DB project can vary an incidence between the parties as they wish. Speculative risks can be within or out of the control of a client and contractor. The suitability of design and build project approach must be carefully undertaken by ensuring the contractor is able to manage the risks. They have to be willing and have relevant experiences to control the risk with success; otherwise the contractor will pass these back to the client. To ensure all parties involved with benefit, risks must be identified, assessed and allocated so that responsibility to bear the risk is most appropriate or effective.

* Corresponding author: sabihah@ymail.com 
The client is now attracted to DB procurement because of several reasons, mainly speed of project time completion, budget cost reduction, simplified contracting and creation of single point responsibility. At the same time, using this kind of contract the contractor is attracted to the high risk. Marques and Berg [1] mentioned that the crucial part of risk management is to identify and allocate risk during planning and construction stage. It is because the contractors in DB project still do not have enough experience and knowledge to identify, allocate and manage risk and effect to the project objective. Therefore, this paper has been carried out to investigate and determine the most responsible parties that should handle the risk in DB project.

\section{Risk allocation in design and build projects}

Risk allocation is an important issue in DB projects. Proper risk allocation to the contracting parties, mainly the contractor, consultant and client will respond to the best result of the project performance. Usually due to lack of information on a risk allocation system, the clients basically transfer the risk more to the contractor. Formerly, contractors respond these risks by increasing their margin of contingencies sum which the contract price would eventually increase. Generally, risk in DB project cannot be handled by one party; it should be two or share parties to that risk.

Banik and Hannan [2] stated that the allocation of risk comes from the owner and contractor or shared by both parties. A total of eight DB construction project risks was allocated to the owner of which site access/right of way, differing site condition, delayed payment on contract, unidentified utilities, permits and ordinances, change in work, Government Acts and Regulation and tax rate change and Acts of God. Furthermore, nine risks were identified among the twenty-six risks that were allocated to the DB contractors. These were namely defective materials, quality of work, safety and accidents, contractor competence, defective design, labour disputes, establishment of a project cost, actual quantities of work and defensive engineering. Meanwhile, the risk factors shared by both the owner and contractor is contract delay resolution, indemnification and hold harmless, financial failure of any party, change order negotiations and third party delay. Further research by Kartam and Kartam [3] supported the results apportionment of construction risk that also comes from owner and contractor or shared by both parties.

El-Seyegh [4] showed in previous studies that fifty-five percent of the respondents indicated that the risks shared between the client and contractor while thirty-eight percent indicated that the risk allocated to the contractor. Meanwhile, the client allocated the risk only seven percent on their responsibility. It is due to the clients in the UAE that are reluctant to share the risk with contractors. Hence, the results of this situation allow the contractor to bid with higher price in the contract that eventually increases the cost of the project.

\section{Research methodology}

This study captured the opinions of Malaysian construction industry which is experienced and knowledgeable on the issues of allocation of risk in DB projects. The knowledgeable can defined as a person having or showing ability an understanding and skill gained through experience by handling a complexity of the projects to solve their problems. A research questionnaire was designed to elicit information from respondents namely client, consultant and contractor. The data was received by mailing and personnel meeting. The respondents were done from Project Director, Project Manager, Contract Manager, Design Manager, Construction Manager, Project Engineer, Quantity Surveyor and Site Supervisor. 
A comprehensive list of 64 risk factors was identified from the literature review and used in the questionnaire survey. Then, a questionnaire survey was conducted to investigate and determine the perceptions of construction experts on risk allocation with different parties involved in DB projects. The questionnaire was divided into two sections. The first section of the questionnaire solicited demographic information about the respondents. The second section consists of three parties (client, consultant and contractor) and who are most responsible and suitable parties that should handle the risk in DB projects. A total of one hundred seventy (170) useable questionnaires were received from the construction experts in DB projects. The results were analysed by using descriptive statistics (frequency analysis) and Kruskal-Wallis test. Kruskal-Wallis $\mathrm{H}$ test is a nonparametric test that can be used to determine the statistically differences between two or more groups of an independent variable.

\section{Data analysis and discussion}

\subsection{Demographic of the respondents}

One hundred seventy (170) of the structured questionnaires survey was received from the group of (client, consultant and contractor) involved directly with DB projects. To ensure the validity of the study, the information of respondents was gather from the respondents' working position and years of experience. The results show that the Project Director representing $18 \%$ of the respondents, followed by Project Manager at 27\%, Construction Manager at $13 \%$, Design Manager at $8 \%$, Contract Manager was represented at $15 \%$, Project Engineer at 12\%, Quantity Surveyor at 4\% and Site Supervisor was represented at $3 \%$ respectively.

Five categories related to the respondents' years of experience were used in this study; $<5$ years experiences representing at $9 \%$ of the respondents, 6-10 years representing at $15 \%, 11-15$ years representing at $11 \%, 16-20$ years representing at $16 \%$ and $>20$ years representing at $49 \%$ which implies that they are sufficiently experiences and knowledgeable in construction industry to answer the questions.

\subsection{Allocation of risk in design and build project}

Based on the survey of overall results, the risk allocations in DB project were shown in Table 1, all 64 numbers of risk allocation perceived by respondents were analysed accordingly to fulfil the objective of this study. The criterion for a risk allocation to be appropriated to a particular category (client, contractor and consultant), was that it should get at least a 50\% response rate. Those that failed to get such response rate in favour of any category were listed as undecided.

According to the survey, Table 1 shows that a total of 41 risk variables had $64 \%$ out of $100 \%$ response rate allocated to the contractor. It appears that the respondents agreed that the contractor should be responsible over these risks. It is not surprisingly to note that the contractor is more responsible to the risk that allocated more than $50 \%$ of the votes, this is probably due to design and build project delivery system. The client awards with a single entity of contract that is responsible for both design and construction of works. Moreover, the DB concept of combining the designer and contractor into a single entity allows the client to shift the risks mostly to the design-builder. Banik and Hannan [2] supported in their studies that the results apportionment of risk allocated more on contractors.

The risks, lack in availability of equipment, late deliveries of materials, lack in availability of skilled labour, difficulties in availability of materials, supplies of defective 
materials, incompetent sub-contractors received (97.1\%, 96.5\%, 96.5\%, 93.5\%, 92.4\%, $95.3 \%$ ), have the highest response rate in favour of the contractor. These risks should best be controlled by the contractor and it is correct that they be allocated [7]. Kartam and Kartam [3] also agreed in their study the availability of labour, material and equipment is the highest response rate. Incompetent sub-contractor is considered with the responsibility or borne by the contractor. From the hierarchy of organization the sub-contractor is appointed by the contractor. So, the contractor is fully responsible on the performance of sub-contractor. Sub-contractor with poor performance refers to the risk of low quality, delayed completion and disputes with general contractor.

The risks, lack of information on safety at site, lack of training on safety at site, lack of coordination with sub-contractor, lack in preparing method statement or shop drawings by contractor, mistake during construction, lack on supervision of labour and works, contractors lack of staff knowledge/experience, lack of payment (delayed progress payment by contractor to the sub-contractor), and high current workload to contractor received $(89.4 \%, 86.5 \%, 88.8 \%, 87.6 \%, 84.1 \%, 84.1 \%, 83.5 \% 82.9 \% 80.6 \%)$, second highest response rate in favour of the contractor. These risks are mostly related to lack in communication among construction parties. Professional team member experience and competency are considered as a key factor in project success that will also be affecting the cost planning and time management. On the other hand, the most effective way is coordinate closely with supplier and sub-contractor. Adafin [5] suggested that if the project team members were well experienced in the construction of the proposed type of project, this could reflect to the project success. It appears that the contractor now realized that there are the best persons to be responsible to handle and control these risks. The information and training should be provided by the contractor and everybody is responsible when entering the construction site. Although the contractor and client are in the best position to control and enforce compliance with safety regulations at site, safety management requires a top down approach [8].

The risks, lack of teamwork, contractor's detailed design does not meet owner's expectation, insufficient time during request for proposal to sub-contractor, lack of suitable organizational structure, lack of information in drafting request for proposal to subcontractor and inadequate cash flow by contractor, received $(77.6 \%, 76.5 \%, 75.9 \%, 74.7 \%$, $72.9 \%, 72.9 \%$ ) third highest response rate in favour of the contractor. The contractor has agreed that these risks come from the management. The contractor considered these risks are allocated to them. Thompson [6] concluded that risk in management is most valuable being implementing at an early stage of the project, which is during design and planning stage. It will be that a major risk might be minimized and avoided. Financial failure must be considered to be the most significant risk category to the contractor or client for the project's objective. Financial risk should consider be borne or responsible by both parties, namely client and contractor.

The risks, insufficient time in preparing tender document to sub-contractor, lack of design-build knowledge/experience/competencies, insufficient time for completion date, lack if quality control and assurance, lack of project manager competency and authority, unforeseen site condition, team members are not participating in technical discussion with owners, insufficient information of site access/right of way and insufficient time to evaluate tender from sub-contractors, received ( $69.4 \%, 68.2 \%, 67.1 \%, 67.6 \%, 65.3 \%$, $65.3 \% 61.2 \%, 62.4 \% 60.6 \%$ ) fourth highest response rate in favour of the contractor. Time management is an important tool for project success. Lack of time management could lead to the project failure time, cost and quality. Hence, the competency, experience and knowledge of project manager drive to project success. The owner who is capable of mobilizing more resources including finances towards site investigations and appointing 
competent parties to conduct the same should be responsible for the risk of unforeseen site conditions.

The risks, unidentified utilities, delay in commencing work because under-estimated time needed to obtain statutory, complexity of the project, insufficient communication between team member to meet project success, lack of standardised systems during tender evaluation, legal disputes during the construction phase among the parties of the contract, lack of communication of design-builder with end users to meet their requirements, Inflation, tax rate exchange, exchange rate fluctuation/devaluation and catastrophes, received $(59.4 \%, 58.8 \%, 58.2 \%, 54.1 \%, 53.5 \%, 53.5 \%, 54.1 \%, 58.2 \%, 57.6 \%, 56.5 \%$, $53.5 \%$ ), the fifth highest response rate in favour of the contractor. Risks of legal disputes during the construction phase among the parties of the contract could originate due to a mistake or misunderstanding by either party. Hence, this risk should really share the risk. Both parties could hedge against them by including clauses in the contract that enable mediation and arbitration. These methods for resolving disputes are becoming popular in Malaysia as opposed to litigation. Inflation, tax rate exchange, rate fluctuation/devaluation and catastrophes should best be shared instead of being the responsibility of the contractor itself [7]. The contract clauses define the requirement and condition for sharing. These are risks where each party may be able to manage it better under different circumstances and could be specified in the contract.

Meanwhile, a total of nine risk variables had $14 \%$ out of $100 \%$ response rate should allocated to the client of which client financial capability, lack of payment (delayed progress payment by owner to the contractor), delay in design approval from client, change of original design from client, owner lack of knowledge and experience, poor supervision by the client, change in government policy, change in government regulation and law and political uncertainty. It appears that the clients have realized the futility of shifting the onus of responsibility to the contractors and are ready to take a more proactive role in the management of such risk factors. Poor management may cause risks pertaining to negotiation. The client is in a better position to manage it by specifying clear and fair contract terms and clear workable procedures.

A total of six risk variables had $9 \%$ out of $100 \%$ response rate should be allocated to the consultant that lack in effectiveness of communication in design, errors of original design, insufficient of original design, insufficient information in contract document, inadequate specification in contract document. The respondents had agreed that the consultant could best manage design, specifications and contract document. Designers may rush to complete the design phase with limited time to the client to start construction early may include a lot of mistakes and defective design occurs. This risk is also related to the quality of design and specification produced by the design professional. This issue might continue during construction phase. The professional designers should improve their design responsibility to fix any deficiency at early planning stage

Lastly, a total of 8 risk variables had $13 \%$ out of $100 \%$ response rate should be allocated to undecided. The respondents who respond to the survey were undecided on the allocation of the following risks; scope of work is uncertainty, actual quantities differ from the contract quantities, redesign because of over budgeted, bureaucracy in government agencies, slow approval permit by BOMBA department, slow approval permit by local authorities, slow approval permit by town planning department and slow approval permit by public work department. Risks pertaining to permits approval should be shared, with client and contractor [7]. Risk of delay in obtaining permit and approval from the government agencies is categorised as unexpected and avoidable. The good relationship between government and construction parties will run project smoothly. These risks should manage and avoid at early stage of the project by early planning on schedule. 
Table 1. Risk allocation in design and build projects.

\begin{tabular}{|c|c|c|c|c|c|}
\hline \multirow[t]{2}{*}{ Risk Description } & \multicolumn{3}{|c|}{ Risk Allocation (\%) } & \multicolumn{2}{|c|}{$\begin{array}{c}\text { Kruskal - } \\
\text { Wallis Test }\end{array}$} \\
\hline & Client & Consultant & Contractor & $\begin{array}{c}\text { Chi- } \\
\text { square }\end{array}$ & $\begin{array}{c}\text { p- } \\
\text { value }\end{array}$ \\
\hline Inadequate cash flow by contractor & 24.1 & 2.9 & 72.9 & 5.993 & 0.050 \\
\hline Client financial capability & 73.5 & 1.8 & 24.7 & 5.364 & 0.068 \\
\hline $\begin{array}{l}\text { Delay in commencing work because } \\
\text { under-estimated time needed to obtain } \\
\text { statutory }\end{array}$ & 14.1 & 27.1 & 58.8 & 5.802 & 0.055 \\
\hline Mistake during construction & 2.9 & 12.9 & 84.1 & 1.462 & 0.481 \\
\hline $\begin{array}{l}\text { Lack of payment (delayed progress } \\
\text { payment by owner to the contractor) }\end{array}$ & 57.6 & 2.9 & 39.4 & 5.692 & 0.058 \\
\hline $\begin{array}{l}\text { Lack of design/build knowledge / } \\
\text { experience / competency }\end{array}$ & 15.9 & 15.9 & 68.2 & 1.939 & 0.379 \\
\hline Insufficient time for completion date & 21.2 & 11.8 & 67.1 & 4.587 & 0.101 \\
\hline Lack in quality control and assurance & 4.1 & 28.2 & 67.6 & 3.193 & 0.203 \\
\hline $\begin{array}{l}\text { Lack of project manager competency and } \\
\text { authority }\end{array}$ & 23.5 & 11.2 & 65.3 & 10.786 & $0.005 *$ \\
\hline $\begin{array}{l}\text { Contractors lack of staffs knowledge / } \\
\text { experience }\end{array}$ & 15.3 & 1.2 & 83.5 & 3.246 & 0.197 \\
\hline $\begin{array}{l}\text { Lack of payment (delayed progress } \\
\text { payment by contractor to the sub- } \\
\text { contractor) }\end{array}$ & 14.7 & 2.4 & 82.9 & 4.056 & 0.132 \\
\hline Incompetent sub-contractors & 4.1 & 0.6 & 95.3 & 4.586 & 0.101 \\
\hline Lack of teamwork & 13.5 & 8.8 & 77.6 & 3.679 & 0.159 \\
\hline $\begin{array}{l}\text { Contractor's detailed design does not meet } \\
\text { owner's expectation }\end{array}$ & 8.8 & 14.7 & 76.5 & 0.337 & 0.845 \\
\hline Lack of coordination with sub-contractor & 2.9 & 8.2 & 88.8 & 13.500 & $0.001 *$ \\
\hline Complexity of the project & 20.6 & 21.2 & 58.2 & 1.820 & 0.403 \\
\hline $\begin{array}{l}\text { Lack of communication of design/builder } \\
\text { with end users to meet their requirements }\end{array}$ & 9.4 & 38.8 & 51.8 & 7.253 & $0.027 *$ \\
\hline $\begin{array}{l}\text { Lack in effectiveness of communication in } \\
\text { design }\end{array}$ & 5.3 & 51.8 & 42.9 & 5.223 & 0.073 \\
\hline Supplies of defective materials & 5.9 & 1.8 & 92.4 & 0.579 & 0.749 \\
\hline Lack in availability of skilled labour & 1.8 & 1.8 & 96.5 & 2.118 & 0.347 \\
\hline Errors of original design & 22.4 & 62.4 & 15.3 & 0.931 & 0.628 \\
\hline Unforeseen site condition & 15.3 & 19.4 & 65.3 & 2.485 & 0.289 \\
\hline Lack of training on safety at site & 5.9 & 7.6 & 86.5 & 15.273 & $0.000 *$ \\
\hline Lack on supervision of labour and works & 4.7 & 11.2 & 84.1 & 10.262 & $0.006^{*}$ \\
\hline $\begin{array}{l}\text { Insufficient communication between team } \\
\text { member to meet project success }\end{array}$ & 19.4 & 26.5 & 54.1 & 7.443 & $0.024 *$ \\
\hline Late deliveries of materials & 2.4 & 1.2 & 96.5 & 2.440 & 0.295 \\
\hline Lack of information on safety at site & 2.9 & 7.6 & 89.4 & 26.323 & $0.000^{*}$ \\
\hline Scope of work is uncertainty & 27.6 & 25.9 & 46.5 & 1.197 & 0.550 \\
\hline Unidentified utilities & 16.5 & 24.1 & 59.4 & 1.596 & 0.450 \\
\hline Insufficient of original design & 25.9 & 58.8 & 15.3 & 2.486 & 0.288 \\
\hline $\begin{array}{l}\text { Team members are not participating in } \\
\text { technical discussions with owners }\end{array}$ & 12.9 & 25.9 & 61.2 & 11.725 & $0.003 *$ \\
\hline Lack in availability of equipment & 1.8 & 1.2 & 97.1 & 0.802 & 0.670 \\
\hline Difficulties in availability of materials & 3.5 & 2.9 & 93.5 & 0.778 & 0.678 \\
\hline Delay in design approval from client & 52.9 & 15.3 & 31.8 & 4.907 & 0.086 \\
\hline High current workload to contractor & 11.8 & 7.6 & 80.6 & 3.369 & 0.186 \\
\hline $\begin{array}{l}\text { Insufficient information in contract } \\
\text { document }\end{array}$ & 24.1 & 60.6 & 15.3 & 3.109 & 0.211 \\
\hline Inadequate specification in contract & 22.4 & 60.6 & 17.1 & 0.218 & 0.897 \\
\hline
\end{tabular}




\begin{tabular}{|c|c|c|c|c|c|}
\hline $\begin{array}{l}\text { document } \\
\text { Insufficient information of site access/right } \\
\text { of way }\end{array}$ & 21.2 & 16.5 & 62.4 & 1.411 & 0.494 \\
\hline Lack of suitable organizational structure & 17.6 & 7.6 & 74.7 & 1.414 & 0.493 \\
\hline $\begin{array}{l}\text { Insufficient time to evaluate tenders from } \\
\text { sub-contractor }\end{array}$ & 17.6 & 21.8 & 60.6 & 9.218 & $0.010^{*}$ \\
\hline Change of original design from client & 52.4 & 35.9 & 11.8 & 4.297 & 0.117 \\
\hline $\begin{array}{l}\text { Legal disputes during the construction } \\
\text { phase among the parties of the contract }\end{array}$ & 27.6 & 18.8 & 53.5 & 2.456 & 0.293 \\
\hline $\begin{array}{l}\text { Lack in preparing method statement or } \\
\text { shop drawings by contractor }\end{array}$ & 2.4 & 10 & 87.6 & 0.619 & 0.734 \\
\hline Exchange rate fluctuation/devaluation & 34.1 & 9.4 & 56.5 & 6.340 & $0.042 *$ \\
\hline $\begin{array}{l}\text { Slow approval permit by BOMBA } \\
\text { department }\end{array}$ & 21.8 & 47.6 & 30.6 & 4.555 & 0.103 \\
\hline $\begin{array}{l}\text { Lack of information in drafting request for } \\
\text { proposals to sub-contractor }\end{array}$ & 5.9 & 21.2 & 72.9 & 4.393 & .111 \\
\hline $\begin{array}{l}\text { Insufficient time in preparing tender } \\
\text { documents to sub-contractor }\end{array}$ & 7.6 & 22.9 & 69.4 & 9.235 & $0.010^{*}$ \\
\hline $\begin{array}{l}\text { Actual quantities differ from the contract } \\
\text { quantities }\end{array}$ & 14.1 & 40 & 45.9 & 1.622 & 0.444 \\
\hline Slow approval permit by local authorities & 32.4 & 38.8 & 28.8 & 2.376 & 0.305 \\
\hline $\begin{array}{l}\text { Slow approval permit by town planning } \\
\text { department }\end{array}$ & 22.9 & 45.3 & 31.8 & 4.932 & 0.085 \\
\hline Redesign because of over budgeted & 47.1 & 34.7 & 18.2 & 0.109 & 0.947 \\
\hline Owner lack of knowledge and experience & 62.4 & 4.1 & 33.5 & 9.334 & $0.009 *$ \\
\hline $\begin{array}{l}\text { Insufficient time during request for } \\
\text { proposal to sub-contractor }\end{array}$ & 9.4 & 14.7 & 75.9 & 8.934 & $0.011 *$ \\
\hline Bureaucracy in government agencies & 40 & 20.6 & 39.4 & 4.026 & 0.134 \\
\hline $\begin{array}{l}\text { Slow approval permit by public work } \\
\text { department }\end{array}$ & 25.3 & 43.5 & 31.2 & 3.515 & 0.172 \\
\hline Catastrophes (Act of God) & 38.2 & 8.2 & 53.5 & 7.832 & $0.020 *$ \\
\hline Poor supervision by the client & 59.4 & 14.1 & 26.5 & 9.794 & $0.007 *$ \\
\hline Inflation & 37.6 & 4.1 & 58.2 & 5.370 & 0.068 \\
\hline $\begin{array}{l}\text { Lack of standardised systems during tender } \\
\text { evaluation }\end{array}$ & 17.1 & 29.4 & 53.5 & 22.178 & $0.000^{*}$ \\
\hline Tax rate exchange & 35.3 & 7.1 & 57.6 & 5.574 & 0.062 \\
\hline Change in government policy & 55.9 & 20 & 24.1 & 6.361 & $0.042 *$ \\
\hline Change in government regulations and law & 53.5 & 19.4 & 27.1 & 4.984 & 0.083 \\
\hline Rigid specifications in contract document & 27.6 & 57.1 & 15.3 & 4.028 & 0.133 \\
\hline Political uncertainty & 64.1 & 8.2 & 27.6 & 3.930 & 0.140 \\
\hline
\end{tabular}

*Indicates that the p-value is less than 0.05

A further analysis was conducted to determine the significance in the differences in the perception of all three parties on risk allocation. Hence, Kruskal-Wallis $\mathrm{H}$ test was conducted to determine whether or several independent items come from the same population. The results of the Kruskal-Wallis test for a k-independent sample shows that the respondent groups had different perceptions on 17 out of 64 variables at the 5 per cent $(\mathrm{P}<0.05)$ significance level, as shown in Table 1; Namely lack of Project Manager Competency and authority, lack of coordination with sub-contractor, lack on supervision of labour and work, insufficient time to evaluate tenders from sub-contractor, insufficient time in preparing tender document to sub-contractor, insufficient time during request for proposal to sub-contractor, lack of standardised systems during tender evaluation, Exchange rate fluctuation/devaluation, catastrophic (Act of God), change in government policy, lack of communication of design-builder with end user to meet their requirements, insufficient communication between team members to meet project success, team members 
are not participating in technical discussions with owner, Change in government policy, lack of information on safety at site and lack of training on safety at site. With these findings the stakeholders play an important role to improve the ability to identify, allocate and manage risk at early stage of the project design and planning. Kartam and Kartam [3] indicated that the method of transfer and share risks is considered to be ineffective for preventing risks. As a matter of fact, the client or general contractors could exercise to practice of shifting the risks to lower hierarchy of organization.

\section{Conclusions}

Risk allocations in DB projects are presented. The results have shown that the contractor is the most responsible parties that should handle the risks inherent in DB projects. Namely, the respondents have allocated 41 risks to the contractor, 9 risks to the client, 6 risks to the consultant and 8 risks undecided. While, the results on Kruskal-wallis test shows 17 risks considered as shared risk on respondents perceptions. The clients have realized the futility of shifting the onus of responsibility to the contractors and are ready to take a more proactive role in the management of such risk factors. Risk in design and build projects cannot be entirely eliminated, but it can be better managed by being appropriately allocated. Literally, the contracting parties must be collaborating to reduce risk by providing as much as possible information to the member of the DB at the beginning of the project design and planning. This can be accomplished by providing detailed information on project stakeholders, objective, characteristics, scope and context. Proper risk allocation will help stakeholders to minimize the occurrence of risk and dispute among contracting parties in DB projects.

\section{References}

[1] R. Marques and S. Berg, Risks, contracts and private-sector participation in infrastructure. J. Constr. Eng. Manage., 925-932, (2011)

[2] G.C. Banik and F. Hannan. Specialty contractors' perspectives on risk importance and allocation of design-build contract, J. of Construction, 1-11, (2003)

[3] N.A. Kartam and S.A. Kartam, Risk and its management in the Kuwaiti construction industry: A contractors' perspective, Int. J. of Project Management, 19(6), 325-335, (2001)

[4] S.M. El-Sayegh and M.H. Mansour, Risk assessment and allocation in highway construction project in the UAE, J. Management Eng., 04015004/1-11, (2015)

[5] J. Adafin, J.O.B. Rotimi and S. Wilkinson, Risk impact assessments in project budget development: Architects' perspectives, Architectural Engineering and Design Management, 1-16, (2016)

[6] P.A. Thompson and J.G. Perry, Engineering construction risks: A Guide to project risk analysis and assessment implications for project client and project managers, Thomas Telford, London, (1992)

[7] R.J. Smith and W. Gavin, Risk identification and allocation saving money by improving contracts and contracting practices, The ASCE Hong Kong International Group and Chartered Institute of Arbitrators, Hong Kong, (1998)

[8] D. Zhao, A.P. McCoy, B.M. Kleiner, TH. Mills and H. Lingard, Stakeholder perceptions of risk in construction, J. of Safety Science, 82, 111-119, (2016) 